\title{
OUTCOME BASED EDUCATION (OBE) IS NEED OF THE HOUR
}

\author{
Dr. G. Thirumoorthy ${ }^{1}$ 政 \\ ${ }^{1}$ Assistant Professor (Guest),Department of Education, Bharathiar University, Coimbatore, 641046, India
}

Received 3 April 2021

Accepted 18 April 2021

Published 30 April 2021

Corresponding Author

Dr. G. Thirumoorthy, gisthirumoor

thy@gmail.com

DOI 10.29121/

granthaalayah.v9.i4.2021.3882

Funding: This research received no specific grant from any funding agency in the public, commercial, or not-for-profit sectors.

Copyright: (C) 2021 The Author(s). This is an open access article distributed under the terms of the Creative Commons Attribution License, which permits unrestricted use, distribution, and reproduction in any medium, provided the original author and source are credited.

OPEN ACCESS

\section{ABSTRACT}

Educational objectives are soul for any educational Programme and it is the prime pillar for sustainable socio-economic development. The holistic educational objectives need to changes according to the social change. To achieve the holistic educational objectives the educational opportunities were decentralized; as a result, worldwide the rate of literates and the percentage of educated people are increased; especially in India was successfully achieved elementary, secondary, and higher education too. Further, the new education policy-2020 insisted to increase the enrolment ratio in higher education from $26.3 \%$ (2018) to $50 \%$ by 2035 . Along with the objectives of increasing the quantitative students' enrolment percentage in higher education, it is the need of the hour to insist on outcome-based education (OBE) for holistic development. Keeping these as a background the researcher intended to describe the OBE as a need of the hour.

Keywords: Outcome Based Education

\section{INTRODUCTION}

Outcome-based education (OBE) is also known as standards-based or accountability in education, the educational theory was initiatedduring late $19^{\text {th }}$ century and rejuvenates in the $21^{\text {st }}$ century which is bases to each part of an educational system. On the other hand, Outcome-Based Education (OBE) is a student-centric teaching and learning methodology in which the course delivery, assessment is planned to achieve specified objectives and outcomes. Outcome-based education is insisting the accountability in teaching and learning. Which includes overall curriculum OBE, subject-based OBE, course-based OBE, Programme-based OBE, etc. At the end of the educational experience, each student would have achieved the goal as an outcome of educational objectives. OBE is extremely be distinguished from the traditional and conventional education method of Teacher-Centered to Learner center by the way it incorporates three elements: theory of education, a systematic structure for education, and a specific approach to instructional practice and experience. The outcome-based educa- 
tion (OBE) or the students' centered education attain the educational goal in terms of individual, competency group, standards, benchmarks, and attainment stipulated targets.

\section{MEANING OF OBE}

Outcome-based education means starting with a clear picture of what is important for students to be able to do, then organizing the curriculum, instruction, and assessment to make sure that this learning ultimately happens (Spady, 1994). OutcomeBased Education is usually expressed in terms of a combination of knowledge, skills and competency, abilities, attitudes, and understanding that a student will attain as a result of his/her successful engagement in a particular set of higher education experiences and opportunities. OBE means clearly focusing and organizing an educational system around what is essential for all students to be able to do successfully at the end of their learning experiences and course.

\section{BRIEF HISTORY OF OBE}

William G. Spady is an academician, educational psychologist, sociologist, educational planner andalso considered the father of Outcome-Based Education (OBE). Spady introduced OBE and coined the term outcome-based education in 1988 as an extension of the works completed by John Franklin Bobbitt and Ralph W. Tyler. The Washington Accord was initiated in 1989; it is an agreement to accept undergraduate engineering degrees courses that were obtained using OBE methods. In 1989 Australia, Canada, Ireland, New Zealand, United Kingdom, United States, in 1995 China, in 1999 South Africa, in 2005 Japan, in 2006 the Singapore, in 2007 Korea, in 2009 in Malaysia, the 2011 Turkey, in 2012 Russia are signatories in Washington Accord to implement the OBE. In 2017, the full signatories are Australia, Canada, Taiwan, Hong Kong, India, Ireland, Japan, Korea, Malaysia, New Zealand, Russia, Singapore, South Africa, Sri Lanka, Turkey, the United Kingdom, Pakistan, China, and the United States. There are many innovations and resolutions were adopted in the National Conference of Vice-Chancellors and Directors on Research \& innovation held between $26^{\text {th }}$ to $28^{\text {th }}$ July 2018. One of the resolutions was to 'Adopt and implement the Learning Outcomes Based Curriculum Framework (LOCF) in Higher Educational Institutions (HEls), by updating the curriculum from academic year 2019-20.

\section{21ST CENTURY EDUCATIONAL OBJECTIVES / OUTCOME TO ATTAIN OBE}

The OBE model measures the progress of students in threeparameters, through:

Program Education Objectives (PEO) and Outcomes - The PEO is narrated in the form of Aim, Vision, Mission, and program objectives and outcomes. Program 
is defined as the specialization or discipline of a Degree. It is the interconnected arrangement of courses, co-curricular and extracurricular activities to adopt and accomplish predetermined objectives leading to the offering a degree. The program objectives/outcomes can be further classified in general and specific and they may differ according to the short-term and long-term educational program. Program outcomes are split into narrower statements that describe what students are expected to be able to do by the time of the duration of program in their career, and also in particular, what the students are expected to perform or achieve after the program in the real world.

Course Outcomes (CO)- it is the measurable and accountable parameter that evaluates each student's performance and learning outcome based on the Blooms' Taxonomy different levels for each course that the student undertakes every semester or subjects. Course outcomes are statements that describe significant and essential learning that learners have to achieved, and can steadfastly demonstrate at the end of a course. Which includes the commitment to excellence in all scholarly and intellectual activities, including critical thinking and judgment, an ability to develop creative and effective / applications responses to intellectual, professional and social challenges, a commitment to sustainability and high ethical standards in social and professional practices, discipline to enable a smooth transition and contribution to professional and community settings. Further, the ability to be responsive to change, to be inquiring and reflective in practice, through information literacy, autonomous in learning, self-managed learning, the ability and competency in communicate and collaborate with individuals, and within teams, in professional and community settings, ability to engage with sundry cultural and indigenous perspectives in both global, regional and local settings.

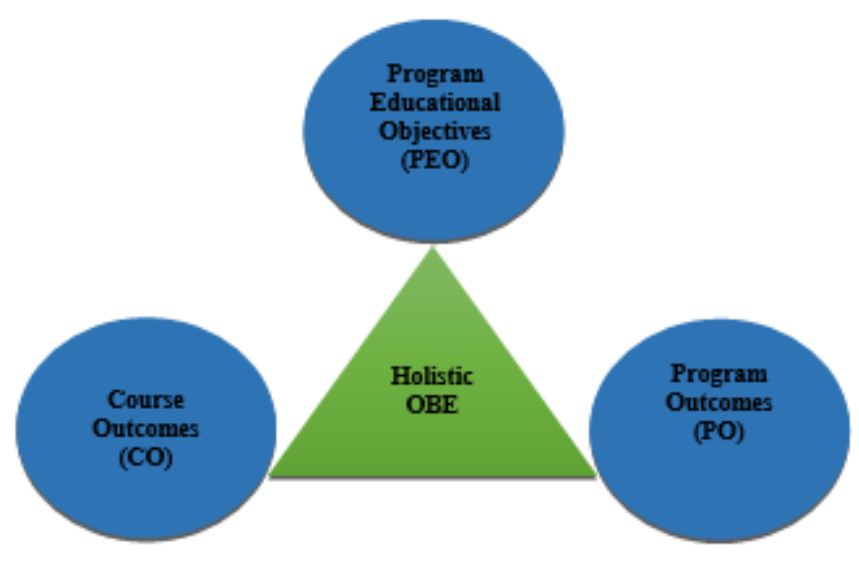

Figure $121^{\text {st }}$ Century Educational Objectives / Outcome to Attain OBE 


\section{21ST CENTURY SKILLS IN OBE}

Skills are learned or some time enhanced traits are the ability to use one's knowledge effectively and readily in execution or performance in a particular situation to attain certain goals. Further, the skills are natural or learned talents and the expertise one to develop and to perform a task or a job. It is the responsibilities of educators, school reformers, college professors, employers, and other stockholders are need to adopt the term $21^{\text {st }}$ century skills includes a broad set of knowledge, skills, work habits, and character traits are to be critically important to success in today's world which include the Education 5.0, Pedagogy 4.0, Industry 4.0, Society 5.0, Global citizen, particularly in education programs and contemporary careers and workplaces.

\section{THE FOLLOWING THREE $21^{S T}$ CENTURY SKILL ARE CAN BE CONSIDER AS FUNDAMENT TO ACHIEVE OBE}

Learning skills - it is the prime skills that include critical thinking - Finding solutions to self and others problems, reasoning and logical thinking, analysis, interpretation, synthesizing and evaluate information, Creativity - Thinking outside the box which include inductive and detective, research and critical thinking skills, practices, interrogative questioning, creativity, artistry, curiosity, imagination, innovation, and personal expression, Collaboration -Working with others which include small and large team, Perseverance and Communication -Talking within (Intrapersonal) to taking with others(Interpersonal), oral and written communication (Language competency), public speaking, presenting, listening, collaboration, co-operation.

Literacy skills- it includes Information literacy - Understanding facts, cultural context, figures, statistics, and data; Media literacy -Understanding the methods and outlets in which information is published; Technology literacy -Understanding the machines that make the Information age possible, data interpretation and analysis, information and communication (ICT),computer programming.

Life Skills - it is very essential for social mobilization. Especially the Flexibility and negligibility - Deviating from strategies as needed, adaptability, adjustability and initiative; Leadership -Motivating self and the team to achieve a goal;Initiative - Starting projects, entrepreneurship, strategies, plans on one's own and others; Productivity - Maintaining efficiency, dynamics and innovation in the world of uncertainty; Social skills - Meeting and networking with other individual, community and other needy one for mutual benefit, civic, ethical, self-direction, planning, self-discipline and social-justice literacy, morality and ethics interpersonal and personal skills are very essential skills for $21^{\text {st }}$ century citizen.

Along with the above the environmental and conservation literacy, ecosystems understanding is very essential for personal health and wellness literacy, including nutrition, diet, exercise, and public health and safety 


\section{BLOOM'S TAXONOMY IS A TOOL TO ACHIEVE OBE}

In 1956, Benjamin Bloom, an American educational psychologist and a group of educational and behavioural psychologists to develop a taxonomy or classification or hierarchy or learning system for learning. They proposed that learning fits into three psychological domains such as the Cognitive domain (processing information, knowledge, and mental skills), the Affective domain (Attitudes and feelings), and the psychomotor domain (manipulative, manual, or physical skills). These three domains are to follow for effective execution of OBE. There are six K-level, or Cognitive levels that have come under three-domain which are Knowledge (Remember), Comprehension (Understand), Application, Analysis, Synthesis (Evaluate), and Apply (Create).

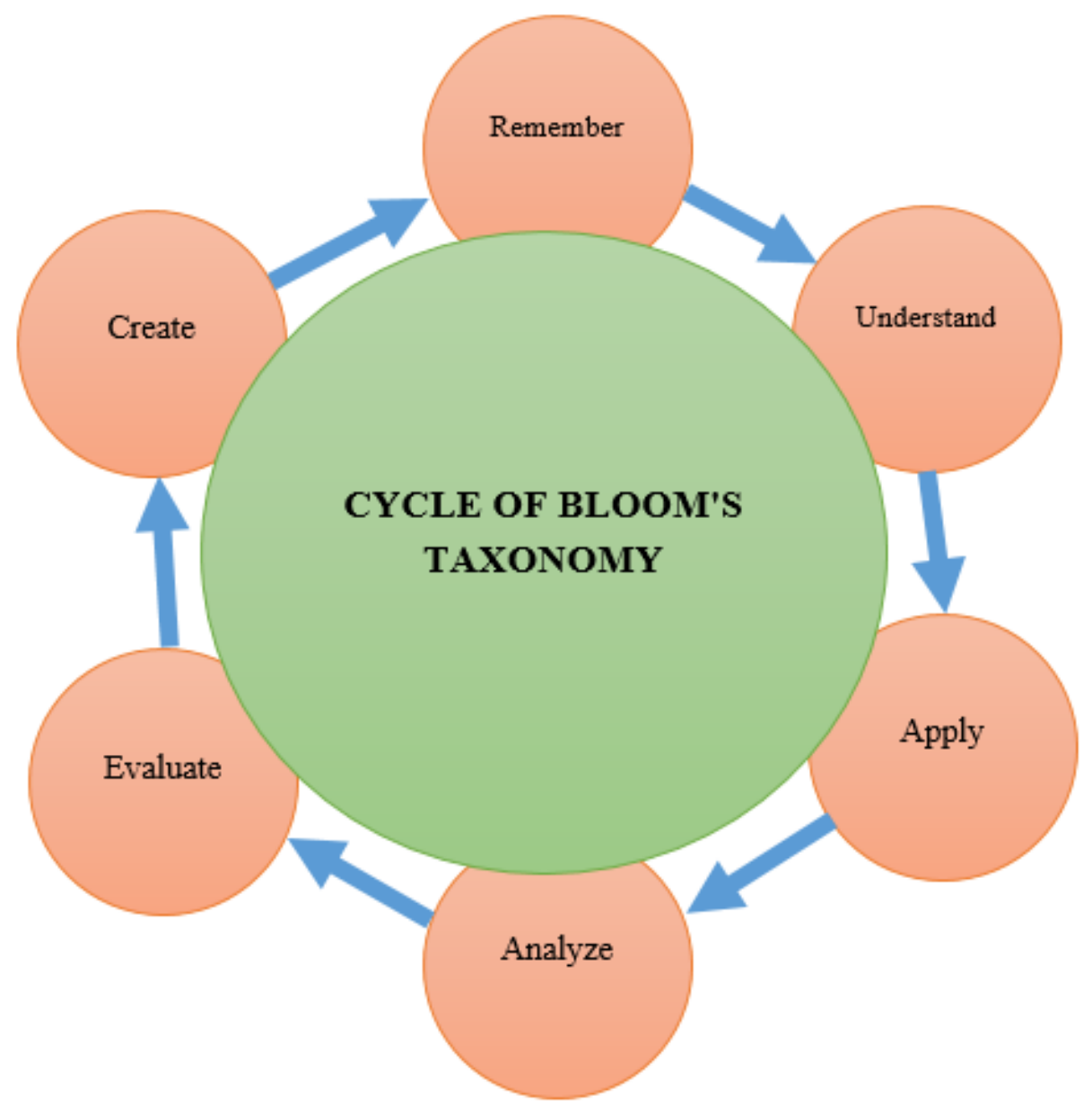

Figure 2 Cycle of Bloom's Taxonomy

Continued on next page 
Table 1 continued

Table 1 K-level, or Cognitive level of Bloom's Taxonomy

\begin{tabular}{|c|c|c|c|c|}
\hline Domains & K - Level & Parameter & Description & Key Words \\
\hline \multirow[t]{4}{*}{$\begin{array}{l}\text { Cognitive } \\
\text { Affective and } \\
\text { Psychomotor } \\
\text { Domain }\end{array}$} & K1 & Remembering & $\begin{array}{l}\text { Recall or retrieve } \\
\text { previous learned } \\
\text { information, } \\
\text { knowledge, } \\
\text { experience, etc. }\end{array}$ & $\begin{array}{c}\text { defines, knows, lists, } \\
\text { matches, outlines, } \\
\text { remember, } \\
\text { recognizes, } \\
\text { reproduces, selects, } \\
\text { states, } \\
\text { identifies,labels, } \\
\text { names, }\end{array}$ \\
\hline & K2 & Understanding & $\begin{array}{c}\text { It involves } \\
\text { demonstrating an } \\
\text { understanding of } \\
\text { facts and ideas by } \\
\text { organizing, } \\
\text { summarizing, } \\
\text { translating, } \\
\text { generalizing, } \\
\text { giving } \\
\text { descriptions, and } \\
\text { stating the main } \\
\text { ideas. }\end{array}$ & $\begin{array}{l}\text { realizes, translates, } \\
\text { differentiates, } \\
\text { assessments, } \\
\text { explains, extends, } \\
\text { generalizes, gives an } \\
\text { example, explain, } \\
\text { compare, gathers, } \\
\text { interprets, } \\
\text { paraphrases, } \\
\text { forecasts, rewrites, } \\
\text { summarizes }\end{array}$ \\
\hline & K3 & Applying & $\begin{array}{l}\text { Use a concept in a } \\
\text { new situation or } \\
\text { unprompted use } \\
\text { of an abstraction. } \\
\text { Applies what was } \\
\text { learned in the } \\
\text { classroom into } \\
\text { novel situations in } \\
\text { the work place, }\end{array}$ & $\begin{array}{c}\text { execution, exchange, } \\
\text { calculates, constructs, } \\
\text { corroborates, } \\
\text { discovers, } \\
\text { manipulates, } \\
\text { modifies, operates, } \\
\text { forecast, prepares, } \\
\text { produces, re-counts, } \\
\text { shows, solves, uses }\end{array}$ \\
\hline & K4 & Analyzing & $\begin{array}{l}\text { Separates material } \\
\text { or concepts into } \\
\text { component parts } \\
\text { so that its } \\
\text { organizational } \\
\text { structure may be } \\
\text { understood. } \\
\text { Distinguishes } \\
\text { between facts and } \\
\text { inferences. }\end{array}$ & $\begin{array}{c}\text { analyzes, breaks } \\
\text { down, associates, } \\
\text { contrasts, } \\
\text { illustrations, } \\
\text { deconstructs, } \\
\text { differentiates, } \\
\text { discriminates, } \\
\text { distinguishes, } \\
\text { identifies, illustrates, } \\
\text { infers, outlines, } \\
\text { relates, selects, splits }\end{array}$ \\
\hline
\end{tabular}




\begin{tabular}{|c|c|c|c|}
\hline Table 1 continued & & & \\
\hline K5 & Evaluating: & $\begin{array}{l}\text { Make judgments } \\
\text { about the value of } \\
\text { ideas or materials. }\end{array}$ & $\begin{array}{c}\text { judges, compares, } \\
\text { concludes, contrasts, } \\
\text { evaluates, critiques, } \\
\text { defends, describes, } \\
\text { discriminates, } \\
\text { evaluates, explains, } \\
\text { interprets, justifies, } \\
\text { relates, summarizes, } \\
\text { supports }\end{array}$ \\
\hline K6 & Creating: & $\begin{array}{l}\text { Builds a structure } \\
\text { or pattern from } \\
\text { diverse elements. } \\
\text { Put parts together } \\
\text { to form a whole, } \\
\text { with emphasis on } \\
\text { creating a new } \\
\text { meaning or } \\
\text { structure. }\end{array}$ & $\begin{array}{c}\text { categorizes, } \\
\text { combines, } \\
\text { accumulates, } \\
\text { composes, creates, } \\
\text { devises, designs, } \\
\text { explains, generates, } \\
\text { alters, organizes, } \\
\text { strategies, } \\
\text { rearranges, } \\
\text { reconstructs, relates, } \\
\text { reorganizes, reviews, } \\
\text { rewrites, } \\
\text { summarizes, } \\
\text { expresses, re- writes }\end{array}$ \\
\hline
\end{tabular}

\section{ASSESSMENT OF OBE OR PERFORMANCE OF RUBRICS}

According to the Eberly Center for Teaching Excellence and Educational Innovation, Carnegie Mellon University (2021) a rubric is a scoring tool that explicitly represents the performance expectations for an assignment or piece of work. A rubric divides the assigned work into component parts and provides clear descriptions of the characteristics of the work associated with each contents and component, at varying levels of mastery and course outcomes. The method of assessment of the candidates during the program is left for the institution to decide. When educators plan curriculums or teachers plan lessons and units for their classes, they usually start by clarifying the purposes. The various assessment tools for measuring Course Outcomes include Mid -Semester and End Semester Examinations, peer evaluation, Tutorials, Assignments, Project work, Labs, Presentations, Employer/Alumni and public Feedback, etc.A rubric can help instructors communicate to students the specific deficiency and requirements and acceptable performance standards of an assignment and evaluation. When rubrics are given to students with the assignment description, they can help students monitor and assess their progress as they work toward clearly indicated short term and long-term goals and achievements. 


\section{TRADITIONAL VERSUS OBE BASED EDUCATION}

Traditional education focuses too much on what the teachers teach as input rather than what the students are learning as outcome. On the other hand, OBE emphasizes a learner-centric self-learning approach. It focuses on the real-world application and experience of education which the student grosses at the end of a Programme, Session, or Course is more important than what or how something is taught. OBE is a progressive model that involves the reform of curriculum, pedagogy, evaluation, and assessment practices to reflect the achievement of high-order learning, thinking and applied knowledge rather than a mere accumulation of percentage of marks and course credits.

Table 2 DIFFERENCE BETWEEN TRADITIONAL AND OBE

\begin{tabular}{|c|c|}
\hline Traditional & OBE \\
\hline The approach is exam-driven. & Learners are assessed on an ongoing basis. \\
\hline $\begin{array}{l}\text { The syllabus is content-based and divided } \\
\text { into subjects. }\end{array}$ & $\begin{array}{c}\text { Content is integrated and learning is relevant, } \\
\text { connected to real-life situations and } \\
\text { experiment-based education. }\end{array}$ \\
\hline $\begin{array}{l}\text { Learning is textbook/worksheet-bound, } \\
\text { subjective and teacher-centered }\end{array}$ & $\begin{array}{l}\text { Learning is objective learner-centered, the } \\
\text { teacher facilitates and constantly applies group } \\
\text { work and team work to consolidate the new } \\
\text { approach }\end{array}$ \\
\hline $\begin{array}{l}\text { The teacher sees the syllabus as rigid and } \\
\text { nonnegotiable. }\end{array}$ & $\begin{array}{l}\text { Learning programmes are seen as guides that } \\
\text { allow teachers to be innovative and creative in } \\
\text { designing their programmes and need based } \\
\text { curriculum. }\end{array}$ \\
\hline $\begin{array}{l}\text { The autocratic teachers are responsible for } \\
\text { learning and motivation depends on the } \\
\text { personality of the teacher. }\end{array}$ & $\begin{array}{l}\text { Learners take responsibility for their own } \\
\text { learning and are motivated by feedback and } \\
\text { affirmation of their worth. }\end{array}$ \\
\hline $\begin{array}{l}\text { Attendance, assignments, exams, activities, } \\
\text { etc. }\end{array}$ & $\begin{array}{l}\text { Achievement of Student Learning Outcomes } \\
\text { (SLOs) }\end{array}$ \\
\hline $\begin{array}{l}\text { Overall undefined and invisible descriptors } \\
\text { for quality of products/holistic grades }\end{array}$ & $\begin{array}{l}\text { Visible descriptors for achievement of SLOs } \\
\text { (Rubric) }\end{array}$ \\
\hline $\begin{array}{c}\text { Grades are derived from cumulative total } \\
\text { number of points on activities, assignments, } \\
\text { exams, etc. }\end{array}$ & $\begin{array}{c}\text { Grades are derived from total points on } \\
\text { assessment of specific SLOs. }\end{array}$ \\
\hline $\begin{array}{l}\text { Grades are offered based on activities, } \\
\text { assignments, tests, etc. }\end{array}$ & $\begin{array}{c}\text { Grades are offered based on links between SLOs } \\
\text { and activities, assignments, tests, etc. }\end{array}$ \\
\hline Learners are passive & Learners are active \\
\hline Defined textbook and lecturer centered & Learner centered \\
\hline $\begin{array}{l}\text { Lecturers responsible for learning and } \\
\text { dependent learning }\end{array}$ & $\begin{array}{c}\text { Learners responsible for their own learning and } \\
\text { independents learning }\end{array}$ \\
\hline Emphasis on what lecturer hopes to achieve & Emphasis on specific outcomes \\
\hline Content placed into rigid time frames & $\begin{array}{l}\text { Flexible time frames and learning ability; learner } \\
\text { determines pace }\end{array}$ \\
\hline Root learning & Critical thinking, reasoning and action \\
\hline $\begin{array}{c}\text { Traditional education that it just transmits } \\
\text { knowledge and understanding of ideas to } \\
\text { students. }\end{array}$ & $\begin{array}{l}\text { Yields students to become outputs rather than } \\
\text { inputs. }\end{array}$ \\
\hline
\end{tabular}




\section{PROCESS AND STEPS TO IMPLEMENTING THE OBE}

Suvin (2018b) imitated the following 20 steps for implementing Outcome-Based Education

1. Need to establish Mission statements and Program Educational Objectives (PEOs)

2. Clear mapping of Mission Statements with Program Educational Objectives is essential

3. Associate and define the Program Learning Objective (PLO) with Bloom's Taxonomy

4. Chart Program Educational Objectives with PLO

5. It is inevitable to Define CO (Course Objectives)

6. Define CLO (Course Learning Outcomes) with Bloom's Taxonomy for each Course

7. Plan Courses with PLO at suitable levels of Bloom's Taxonomy

8. Map CLO with PLO at appropriate levels of Bloom's Taxonomy

9. Draw Assessment Pattern with CLO of each course

10. Map target Topics with CLOs

11. Define pedagogical tools and teaching strategies for course outcomes delivery

12. Preparing session-wise Course unit planand lesson planner

13. Map Questions with CLOs at Bloom's Taxonomy levels \& Assessments

14. Define rubrics assessment and evaluation with Bloom's Taxonomy and CLO

15. Monitor students' performance by offering proper remedial measures

16. Measure students' performance against CLO threshold, course-wise

17. Measure students' performance against Program Learning Objective (PLO) threshold, semester-wise

18. Measure the attainment of each PLO through Direct/Indirect assessments

19. Associate PLO for last 3 academic years and propose remedial actions

20. Assess the achievement of Program Educational Objectives

\section{ADVANTAGES OF OBE}

The advantage is that outcome-based education imparts thinking skills and engages students more actively. When the student creates a product is much more meaningful than answers on a test or paper pencil evaluation. Outcome-based education (when done right) provides learning more similar to real-world applications and real-world problem salving.

Clarity in Concept- The emphasis on outcomes creates a clear anticipation of what needs to be inculcated and proficient by the end of the course or Programme. Students will get to know what is expected of them and teachers will understand 
what they need to teach during the course and Programme. Clarity is essential besides years of schooling and when teaching is accomplished as a team.

Clarity helps each learner to have a clear understanding of what needs to be accomplished in each class, or at each level and pre-defined standard building students' progress. The people who are delineation and planning the curriculum objectives are expected to work once the outcome has been decided and delimited. The curriculum farmworker needs to determine what knowledge and skills will be required to arrive at the outcome.

Flexibility in Choice of Contents -Any method can be chosen to teach a student according to the learning style and ability to learn. OBE does not limit the teachers to teach using a specific method and gives to freedom to adopt customized strategies. OBE is a holistic and modern student-centered learning model and strategies. Teachers are meant to guide, mentor, facilitate and help the students master the material using either approach.

Students Voluntary Involvement learning - Student involvement in the classroom is a key part and it is inevitable of OBE. Students are expected to do selfmotivated and self-engaged in learning so that they attain a full understanding of the material and core concept. It increases student involvement and allows students to feel responsible for their own learning. On the other hand, the parents and societies are indirect and moral helper for students learning outcomes.

\section{DEMERITS OF OBE}

- The disadvantage of OBE cannot applicable while accounting in feelings, values, attitudes, and beliefs over attaining factual knowledge are becoming very challenging. Outcome-based education also relies on evaluations that are subjective, rather than objective tests and measurements.

- Outcome-based education starts through given common operation elaborated by the outsiders rather than the interest, needs, and bond examined by the teachers, students, and parents in their own situation.

- Substantial amount of work is required for the planning, design, and development of a training Programme.

- In OBE there is no specified style or methodology of teaching or assessment and evaluation, the most important is that it should help the students to achieve the specified outcomes which are becoming crucial.

- While implementing the OBE it is inevitable to implement the alternative assessment tools, such as rubrics, concept maps and mind mapping, portfolios, student Journals, self-assessments, and peer group assessments are needed to determine what students have actually known and understand where they are in the learning process. 


\section{SUMMARY}

From the ancient period, there was a huge innovative methodology introduced in teaching, learning, and evaluation which leads catastrophic increases in the quantity of education. But, the 21st century is focusing on quality, accountability, and outcome. Especially the outcome-based education is need of the hour to overcome unemployment, for economic sustainability, and to fit the youth to the global citizen. Traditional education systems are gradually losing their significance in the age of globalization. The changes take place very quickly and continually in today's globe. More skills are needed to cope with the modern world. Therefore, it is unavoidable to move from traditional education to outcome-based education. But huge questions arise about how the learner-centric approach or outcome-based education (OBE) will be beneficial and here is how this system will be beneficial.

\section{REFERENCES}

Carnegie Mellon University. (2021).:\%7e:Text=A\%20rubric\%20is\%20a\%20scoring,At\%20varying\%20 Retrieved from Https://Www.Cmu.Edu/.Https://Www.Cmu.Edu/Teaching/ Designteach/Teach/Rubrics.Html\#

Abbhilash, M. (2018). Things You Need To Know About Outcome-Based Education In India. 4 Things You Need To Know About Outcome-Based Education In India. Retrieved from Https://Www.Myklassroom.Com/.Https://Www.Myklassroom.Com/ Blog/4-Things-To-Know-About-Outcome-Based-Education/

Chairman And Deputy Chairman (N.D.). Washington Accord. (2021). Retrieved from Https:// Www.Ieagreements.Org/Accords/Washington/

Contributors, W. (2021). Rubric (Academic). Retrieved from Https://En.Wikipedia.Org/Wiki/ Rubric_

Iloanya, J. (2019). Preparing The 21st Century Teacher For The Implementation Of OutcomesBased Education. American Journal of Educational Research, 7, 439-444. Retrieved from https://dx.doi.org/10.12691/education-7-7-2 10.12691/education-7-7-2

Mcdaniel, R. (2021). Bloom's Taxonomy. Retrieved from Https://Cft.Vanderbilt.Edu/Guides -Sub-Pages/Blooms-Taxonomy/

October). 21st Century Knowledge And Skills In Educator Preparation. (2010). American Association Of Colleges Of Teacher Education(1).

An Overview Of Outcome-Based Education. (2021). In B. B. (N.D. (Ed.), An Overview of Outcome-Based Education. Retrieved from Http://Www.Ascd.Org/Publications/ Curriculum_Handbook/413/Chapters/An_Overview_Of_Outcome-Based_Education .Aspx

Spady, L., And, W., \& Marshall, K. (1991). Beyond Traditional Outcome-Based Education. Beyond Traditional Outcome-Based Education, 2, 67-72.

Stauffer, B. (2021). What Are 21st Century Skills? Applied-Educational-Systems. Retrieved from Https://Www.Aeseducation.Com/Blog/What-Are-21st-Century-Skills

Suvin, M. C. (2018a). Outcome Based Education Obe - What Is It All About? . Outcome Based Education Obe - What Is It All About? / Creatrix Campus. Retrieved from Https://Www.Scribbr.Com/.Https://Www.Creatrixcampus.Com/Blog/Outcome -Based-Education-What-Is-It-All-About

Suvin, M. C. (2018b). Step Guides For Implementing Outcome-Based Education. 20 Step 
Guides For Implementing Outcome-Based Education / Creatrix Campus. Retrieved from Https://Www.Creatrixcampus.Com/.Https://Www.Creatrixcampus.Com/Blog/ 20-Step-Guide-Implementing-Outcome-Based-Education

Vickery, T. R. (1990). Oddm: A Workable Model For Total School Improvement. Educational Leadership, 47, 67-71.

Watanabe-Crockett, L. (2020). The Critical 21st Century Skills Every Student Needs And Why. The Critical 21st Century Skills Every Student Needs And Why. Retrieved from Https://Wabisabilearning.Com.Https://Wabisabilearning.Com/Blogs/ Literacy-Numeracy/Skills-Every-Student-Needs 